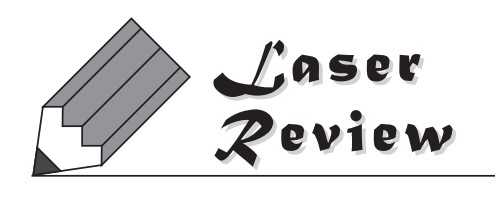

\title{
高出力・波長可変テラヘルツ光パラメトリック光源
}

\author{
林 伸一郎 ${ }^{1}$, 縄田 耕二 1 , 川瀬 晃道 $^{1,2}$, 南出 泰覀 $^{1}$ \\ '理化学研究所 ( $=980-0845$ 仙台市青葉区荒巻字青葉519-1399) \\ 名古屋大学 ( $7464-8603$ 名古屋市千種区不老町)
}

\section{High-Peak-Power, Tunable Terahertz-Wave Parametric Source}

\author{
Shin 'ichiro HAYASHI, ${ }^{1}$ Koji NAWATA, ${ }^{1}$ Kodo KAWASE, ${ }^{1,2}$ and Hiroaki MINAMIDE ${ }^{1}$ \\ ${ }^{1}$ RIKEN ASI, 519-1399 Aramakiaoba, Aoba, Sendai, Miyagi 980-0845 \\ ${ }^{2}$ Nagoya University, Furo-cho, Chikusa, Nagoya, Aichi 464-8603
}

(Received March 26, 2012)

\begin{abstract}
We report on the development of a high-peak-power, single-longitudinal-mode and tunable injectionseeded terahertz-wave parametric generator using $\mathrm{MgO}: \mathrm{LiNbO}_{3}$, which operates at room temperature. The high peak power $(>120 \mathrm{~W})$ is enough to allow easy detection by commercial and calibrated pyroelectric detectors, and the spectral resolution $(<5 \mathrm{GHz})$ is the Fourier transform limit of the subnanosecond terahertz-wave pulse. The tunability $(1.2-2.8 \mathrm{THz})$ and the small footprint size (A3 paper, $29.7 \times 42 \mathrm{~cm})$ are suitable for a variety of applications.
\end{abstract}

Key Words: Terahertz wave, Far-infrared lasers, Frequency conversion, Parametric amplifiers

1. はじめに

近年, 遠赤外線あるいはサブミリ波の領域において新 しい発生・検出方式の研究が急速に進展しつつあり, そ れに伴ってテラヘルツ光という言葉がよく用いられるよ うになった，テラヘルツ光とは，マイクロ波と赤外光の 間に位置する電磁波であり, $1 \mathrm{THz}\left(10^{12} \mathrm{~Hz}\right)$ 付近の周波 数を持つことからこう呼ばれている. テラヘルツ光の厳 密な定義はまだ存在しないが, およそ周波数が 0.3 $10 \mathrm{THz}$ ，波長に換算すると $1 \mathrm{~mm} \sim 30 \mu \mathrm{m}$ の領域を指す. このテラヘルツ光領域に関する研究は, 基礎科学応用か ら産業応用まで様々な分野において独自の応用開拓を目 指して多数のテラヘルツ光応用の提案がなされ, 論文報 告数も年々増加する傾向にある。この背景には, テラへ ルツ波領域の開発が成熟した光技術や超高速エレクトロ ニクスの技術を基盤として飛躍的に進歩してきたことが 挙げられる ${ }^{1-3)}$ 。 これまで, 様々なテラヘルツ光領域に おける電磁波の特徽が報告されている。例えば, 「電波 のように」紙やプラスチック, ビニール, 繊維, 半導体, セラミクス, 脂肪, 粉体, 水など様々な物質を透過する 性質を持つと共に，「光波のように」レンズやミラーで空 間を自在に取り回すことができ, 電波に比べて波長が短 いため, 多くのイメージング用途にとって必要十分な波 長 $(100 \mu \mathrm{m})$ 程度の空間分解能を有していることや, ビ 夕ミンや糖, 医薬品, 農薬, 禁止薬物, 爆薬など様々な 試薬類に固有の吸収スペクトル（指紋スペクトル）が
$3 \mathrm{THz}$ 以下の低周波数領域で見出されていることが挙げ られる。これらの特性を直接用いた利用方法が数多く提 案されることで，テラヘルツ光を利用する新しい応用分 野の開拓に繋がってきた，最近では，テラヘルツ光研究 がそれぞれの分野で発展し始め, これまでこの領域の光 源・検出器が未発達のために解明されていない物理現 象・生命現象・物質構造の解明, および宇宙, 大気や生 体，プラズマなどの計測・診断，さらにはテラヘルッ光 による非線形現象など幅広い基礎的研究分野に関する専 門的な議論が多数なされつつあり ${ }^{4-7)}$, この周波数帯の 電磁波の特徵を生かしたイメージング, 非破壊計測, 爆 薬・禁止薬物検出, バイオテクノロジーや医学への応 用，および様々な産業応用への可能性など，テラヘルツ 光研究は今後ますます重要になることが予想される.

しかしながら, この領域は, 光波と電波のそれぞれの 領域が重要な応用技術とともに発展・成熟してきたのと は対照的に, 発生および検出技術面および応用面共に開 拓が遅れているが, 近年, レーザー光の波長変換を用い て比較的簡便にテラヘルツ光発生が実現できるように なってきた。最も一般的なテラヘルツ光の発生・検出方 法は, 電気光学結晶や光伝導アンテナ, 半導体, 超伝導 体等をフェムト秒レーザーで励起して広帯域なテラヘル ツ光パルスを発生・検出するテラヘルツ時間領域分光法 ( $\underline{\mathrm{THz}} \underline{\mathrm{Time}} \underline{\text { Domain }} \underline{\mathrm{Spectroscopy}})^{8-11)}$ である.このTHzTDSは, 従来の熱型光源を用いた遠赤外フーリエ変換分 光光度計に比べて非常に感度が高く, 物質のテラヘルツ 
分光やイメージング等に応用され成果を上げている.

一方で, 物質の特定量子状態への励起, 超高分解能の 分光, 超高速光エレクトロニクス等への応用にはスペク トル線幅の狭い周波数可変テラヘルツ光源が必要であ る. 現在, 周波数 $1 \mathrm{THz}$ 程度以下の領域では, 比較的コ ンパクトで発振スペクトル幅の狭い周波数可変な光源で ある後進波管(Backward Wave Oscillator)が利用できる が, 寿命が数百時間程度と短く, BWOの出力が急減す る $1 \mathrm{THz}$ 以上の高周波領域での光源開発は遅れている. この領域における広帯域周波数可変テラヘルッ光源に

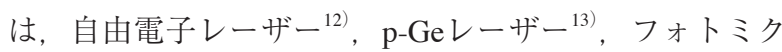
サー ${ }^{14)}$ な゙があるが，それぞれシステムが大規模であ る, 極低温を要する, 出力が低いなどの課題を抱えてい る. また, 中赤外域で高出力を実現している量子カス ケードレーザー ${ }^{15)}$ ヶ, 原理的に波長可変性に乏しく, $3 \mathrm{THz}$ 以下の領域では, 数例の報告例はあるものの現在 はレーザー発振が困難である。このため, コンパクトで 室温動作可能かつ簡便な高出力テラヘルツ光源が実現す れば, この領域における非線形分光 ${ }^{16,17)}$ 等の新たな研究 が飛躍的に進展するのは間違いない.

このような背景の下, 我々は非線形光学効果 (ニオブ 酸リチウム $\left(\mathrm{LiNbO}_{3}\right)$ 結晶中の誘導ポラリトン散乱現 象 $^{18,19)}$ )を用いたパラメトリック波長変換によるテラへ ルツ光源(テラヘルッ光パラメトリック発生器:

Terahertz-wave Parametric Generator, およびテラヘルツ光 パラメトリック発振器： TP Oscillator, 光注入型テラヘ ルッ光パラメトリック発生器 : Injection-Seeded TPG) の 研究に取り組んでいる ${ }^{20)}$. 本光源は非線形光学結晶と励 起光源だけでテラヘルツ光を発生させるため, 小型簡便 かつ室温動作可能であり, $\mathrm{LiNbO}_{3}$ 結晶のパラメトリッ ク利得の広帯域性から, 周波数領域も $1 \mathrm{THz}$ 以下から $3 \mathrm{THz}$ 以上と広い. 従来, テラヘルッ光パラメトリック 光源の出力を制限していた要因のひとつは, 非線形光学 結晶の損傷しきい值である.テラヘルツ光の波長制御 は, 共振器によってアイドラー光を選択することによっ て実現できるが，その波長選択性向上のためには，共振 器長よりも十分に長いパルス幅を持つ励起光が必要であ る.このため, 励起光のパルス幅を維持したまま高強度 化していくと, 非線形光学結晶の熱的な損傷しきい值に 達してしまい, 高強度励起によるテラヘルツ光の高出力 化が困難であった。これに対し，アイドラー光の選択を 光注入によって行えば，パルス幅の制約なく短いパルス 幅の励起光源を用いることができるので，損傷しきい值 が上昇し, 高強度励起による高出力化が期待できる. 本 稿では, 高出力・波長可変テラヘルッ光パラメトリック 光源を目指し, サブナノ秒のパルス幅を持つ励起光源を 用いた光注入型テラヘルッ光パラメトリック光源につい て述べる。

\section{2. テラヘルツ光パラメトリック発生の原理}

パルスレーザーのような強電場を持つ電磁波が横光学 フォノンモードをもつ非線形光学結晶を通過すると,
フォトンとフォノンが結合してポラリトンと呼ばれる素 励起状態を形成する. Fig. 1に, 非線形光学結晶として $\mathrm{LiNbO}_{3}$ を利用した場合のポラリトンの分散曲線を示 す. 共鳴周波数 $\omega_{\mathrm{T}}$ 付近ではフォノンライクに振舞うが, 共鳴周波数から十分離れた低周波数領域ではフォトンラ イクに振舞う。このため, ポラリトンを介した誘導ラマ ン散乱(誘導ポラリトン散乱)によって, 広帯域なテラへ ルツ光発生を行うことができる。誘導ポラリトン散乱 は, $\mathrm{LiNbO}_{3}$ や $\mathrm{LiTaO}_{3}, \mathrm{GaP}$ どの極性結晶で観測される ことが報告されている ${ }^{21)}$. 特に $\mathrm{LiNbO}_{3}$ は, 可視〜近赤外 領域で広帯域に $(0.4-5.5 \mu \mathrm{m})$ 強い吸収がなく，光損傷に 対する耐性が高く(損傷限界>数百 $\left.\mathrm{MW} / \mathrm{cm}^{2}\right)^{22}$, 誘導散 乱で高い利得が得られ，テラヘルツ光の結晶中のロスが 他の材料に比べて小さい ${ }^{23}$ ，などの特性をもつことから 高出力, 広帯域なテラヘルツ光発生に有利である。

誘導ポラリトン散乱過程では, 励起光 (周波数 $\omega_{p}$ ) とア イドラー光 $\left(\omega_{i}\right)$, ポラリトン $\left(\right.$ テラヘルツ光 $\left.; \omega_{T}\right)$ の間 に, エネルギー保存則 $\omega_{p}=\omega_{i}+\omega_{T}$ と運動量保存則 (ノン コリニア位相整合条件) $\boldsymbol{k}_{p}=\boldsymbol{k}_{i}+\boldsymbol{k}_{T}$ が成立し，屈折率の波 長分散特性のために励起光の光軸からの散乱角に応じて アイドラー光およびテラヘルツ光の波長が定まる. 光強 度が〜 $100 \mathrm{MW} / \mathrm{cm}^{2}$ 程度以上のナノ秒パルスレーザーを 用いてシングルパスで $\mathrm{LiNbO}_{3}$ 結晶 $\left(\mathrm{A}_{1}\right.$ 対称モードの最低 準位： $\left.\omega_{\mathrm{TO}}=250 \mathrm{~cm}^{-1}=7.5 \mathrm{THz}\right)$ を励起すると，帯域が $1 \mathrm{THz}$ 超えるアイドラー光およびテラヘルツ光の発生 が観測される。本稿では，このシングルパス励起の広帯 域なテラヘルッ光の発生をテラヘルッ光パラメトリック 発生と呼ぶ.

テラヘルッ光パラメトリック発生の利得幅は, パラメ
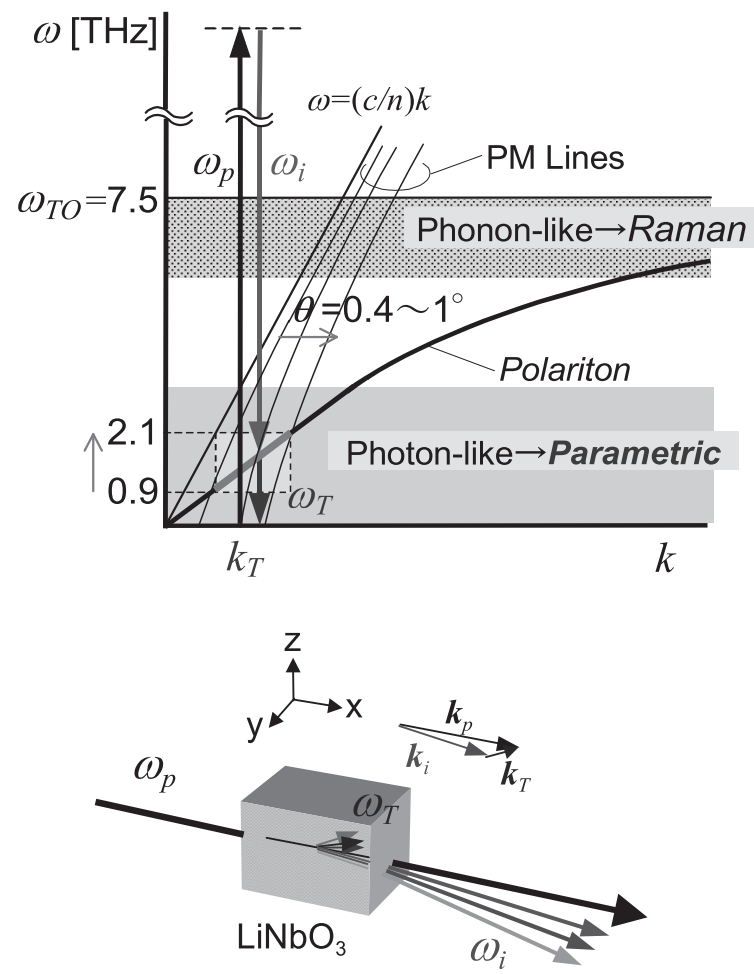

Fig. 1 The dispersion relation of the polariton and the noncollinear phase matching condition in $\mathrm{LiNbO}_{3}$. 


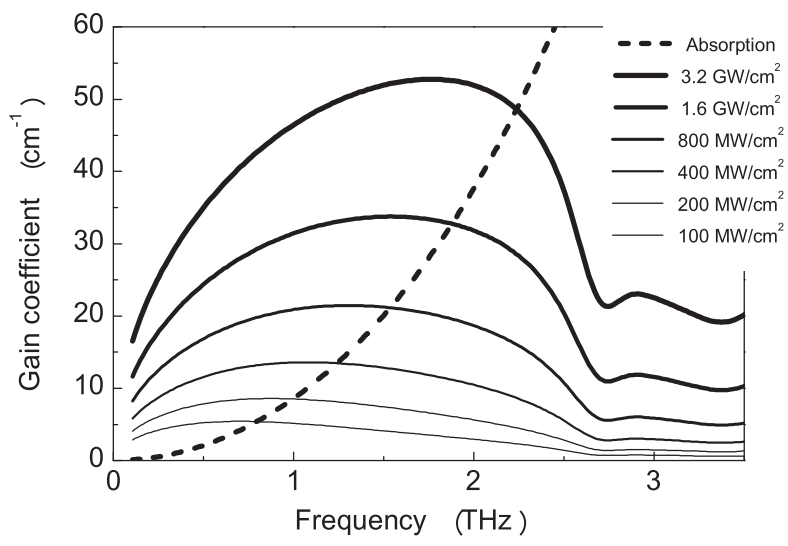

Fig. 2 Calculated gain coefficient for terahertz wave generation using $\mathrm{MgO}: \mathrm{LiNbO}_{3}$ crystal pumped at $1064 \mathrm{~nm}$

トリック利得と非線形光学結晶によるテラヘルツ光の吸 収によって決まり，共鳴周波数から十分離れた低周波領 域において，平面波近似の下でノンコリニア位相整合条 件 $\left(\boldsymbol{k}_{p}=\boldsymbol{k}_{i}+\boldsymbol{k}_{T}\right)$ を考慮して求めると, パラメトリック利 得 $g_{T}$ は,

$$
g_{T}=\frac{\alpha_{T}}{2}\left\{\sqrt{1+16 \cos \phi\left(\frac{g_{0}}{\alpha_{T}}\right)^{2}-1}\right\}
$$

と表される. ここで, $\phi$ は励起光とテラヘルッ光の間の 位相整合角, $g_{0}$ は低ロス限界でのパラメトリック利得, $\alpha_{T}$ はテラヘルツ光の吸収係数を表し,

$$
\begin{gathered}
g_{0}=\sqrt{\frac{\pi \omega_{p} \omega_{i} I_{p}}{2 c^{3} n_{T} n_{i} n_{p}}} \chi_{p} \propto \sqrt{\omega_{i} \omega_{T} I_{p}} \\
\chi_{p}=d_{E}+\frac{S_{0} \omega_{0}^{2}}{\omega_{0}{ }^{2}-\omega^{2}} d_{Q} \\
\alpha_{T}=\frac{2 \omega}{c}\left|\operatorname{Im}\left(\sqrt{\varepsilon_{T}}\right)\right|
\end{gathered}
$$

である ${ }^{24)}$ 。ただし， $I_{p}$ は励起光強度， $c$ は真空中の光速， $n_{T}, n_{i}, n_{p}$ はそれぞれ，テラヘルッ光，アイドラー光， 励起光の屈折率, $S_{0}$ は振動子強度, $\omega_{0}$ は $\mathrm{A}_{1}$ モードの共鳴 周波数, $d_{E}, d_{Q}$ はそれぞれ電子分極，イオン分極に起因 した 2 次と 3 次の非線形光学過程, $\varepsilon_{T}$ は誘電率を表す.

東北大の四方らは, 一致溶融組成 $\mathrm{LiNbO}_{3}$ 結晶を $\mathrm{X}(\mathrm{ZZ}) \mathrm{Y}$ 配置で測定したラマンスペクトルの解析によ り, $\mathrm{A}_{1}$ モードの固有周波数および線幅(減衰定数)を決 定し, 周波数依存性を示した ${ }^{24)}$. Fig. 2に, これらの結 果を用いてパラメトリック利得(1) 式を計算した結果を 示す. 非線形結晶を高強度で励起した場合, $3 \mathrm{THz}$ 以上 の領域に及ぶ周波数領域にわたって数 $\mathrm{cm}^{-1}$ 以上の高い利 得を有することがわかる。

\section{3. 実験装置}

Fig. 3に, 実験装置の概要を示す。実験装置は, 励起 光源 (Microchip Nd: YAG laser), 半導体励起光増幅器

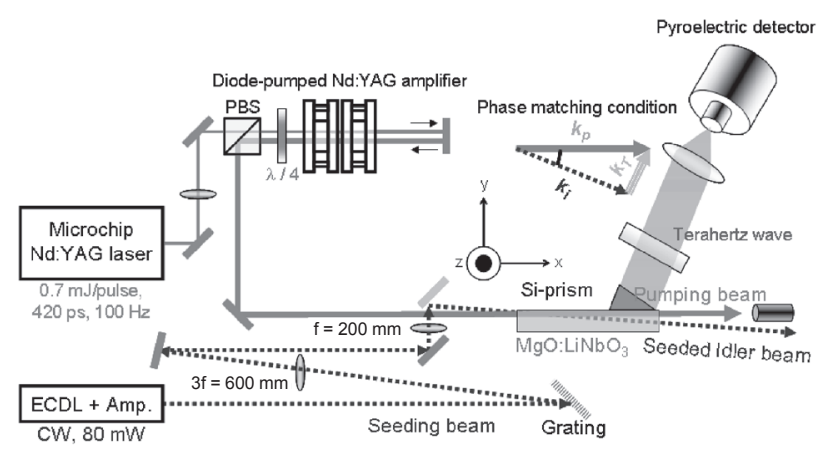

Fig. 3 Experimental setup.

(Diode Pumped Nd: YAG amplifier), 注入光源(外部共振 器型半導体レーザー+光増幅器: ECDL + amp.), 非線 形光学結晶 $\left(\mathrm{MgO}: \mathrm{LiNO}_{3}\right)$, 焦電素子型検出器 (Pyroelectric Detector)によって構成される。励起光源として, サブナ ノ秒のパルス幅をもつマイクロチップNd:YAGレー ザー ${ }^{25,26)}$ を用いた。 この励起光源は, 尖頭值出力 $1 \mathrm{MW}$ 以上 (エネルギー0.7 mJ/pulse, パルス幅 $420 \mathrm{ps}$ ), 単一縦 モード発振 (線幅 $<0.009 \mathrm{~nm}$ ), 繰り返し $100 \mathrm{~Hz}$ である.

また, 過飽和吸収体 $\left(\mathrm{Cr}^{4+}: \mathrm{YAG}\right)$ による受動Qスイッチ動 作のため電気ノイズが少なく, 出力摇らぎも $\pm 2 \%$ と小 さい.

光増幅器によって増幅された励起光を, 両端面に励起 光 $(1064 \mathrm{~nm})$ に対する無反射膜を施した非線形光学 $\left(\mathrm{MgO}: \mathrm{LiNbO}_{3}\right)$ 結晶 $(4 \times 5 \times 65 \mathrm{~mm})$ に入射した. 励起光 は結晶中を，ノンコリニア位相整合条件を満たす方向に アイドラー光およびテラヘルツ光を発生させながら通過 する。このとき, 注入光 (連続波, 出力 : $80 \mathrm{~mW}$, 波 長：1068-1075 nm)の波長を選択すると, 回折格子と結 像光学系によって, 結晶入り口において励起光とのノン コリニア位相整合条件を満たすように入射角度が決まる よう調整しておき, 注入することによってテラヘルツ光 の波長を選択する。

$\mathrm{MgO}: \mathrm{LiNbO}_{3}$ 結晶は数 $\mathrm{THz}$ 帯に大きな吸収係数 $(10$ $\left.100 \mathrm{~cm}^{-1} @ 1 \sim 3 \mathrm{THz}\right)$ を持つため, 効率よくテラヘルツ光 を取り出すためには, 結晶の取り出し面近くを励起しな ければならない，本研究では，出力テラヘルッ光が最大 になるように調整した結果, 結晶端面からの距離と励起 光のビーム径は同程度である。発生したテラヘルッ光 は，結晶のy面に圧着したシリコン製プリズムによって 結晶外に取り出され, レンズ系で集光後, 焦電素子型検 出器 (SpectrumDetector社製：SPI-A-65 THZ)によって検出 される。

また，発生したテラヘルツ光を検出するための光学系 を除くと, テラヘルッ光パラメトリック発生に必要な部 分は, 励起光源に小型のマイクロチップNd:YAGレー ザーを使用したことで，A3用紙程度 $(29.7 \times 42 \mathrm{~cm})$ 程度 と非常に小型である。

\section{4. 結果および考察}

Fig. 4に, 周波数 $1.8 \mathrm{THz}$ のきのテラヘルツ光出力の 励起光強度依存性を示す. 励起光強度が上昇し, 


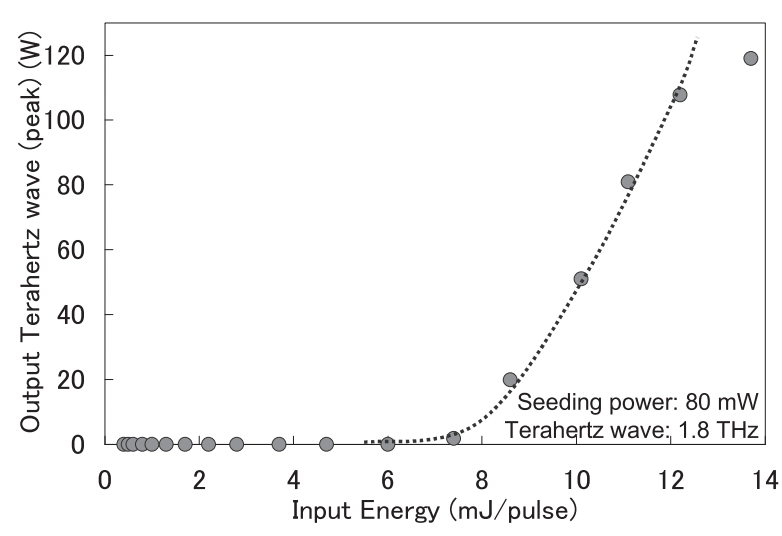

Fig. 4 Pumping energy dependence of terahertz-wave.

$6 \mathrm{~mJ} / \mathrm{pulse}\left(1.5 \mathrm{GW} / \mathrm{cm}^{2}\right)$ 付近に達するとテラヘルツ光が 観測され始め, 励起光エネルギーの増加に伴ってテラヘ ルツ光出力は単調に増加する. 励起光強度が $14 \mathrm{~mJ} / \mathrm{pulse}$ $\left(3.5 \mathrm{GW} / \mathrm{cm}^{2}\right)$ のとき, 最高のテラヘルツ光出力, 約 $120 \mathrm{~W}$ (尖頭值) が観測された。 このとき, 注入光を遮断 すると, 出力は $100 \mathrm{~mW}$ (尖頭值) 以下にまで減少した. 単一縦モード動作のフラッシュランプ励起Qスイッチ

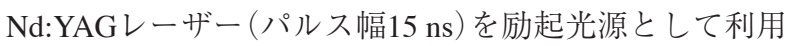
した場合と比較すると, 非線形光学結晶の損傷しきい值 は $450 \mathrm{MW} / \mathrm{cm}^{2}$ から $3.5 \mathrm{GW} / \mathrm{cm}^{2}$ 以上へと改善されたこと によって, 高強度励起が可能になり大幅な出力向上を達 成した。 これは, 励起光のパルス幅が短いため, 励起光 強度は大幅に上昇したにもかかわらずエネルギーは小さ く抑えられており, 非線形光学結晶の熱的な損傷を避け ることができたために実現されたと考えられる。

Fig. 5に, テラヘルツ光出力の周波数依存性を示す. 励起光のエネルギーが $12 \mathrm{~mJ} / \mathrm{pulse}$, 注入光の出力が $80 \mathrm{~mW}$ のき, 注入光の波長と励起光とのなす角を, ノ ンコリニア位相整合条件を満たすように変化させること によって，1.2-2.8 THzの範囲でテラヘルツ光の発生を 観測した. 最大のテラヘルツ光出力は, $1.8 \mathrm{THz}$ 付近に おいて約 $110 \mathrm{~W}$ (尖頭值)であった。この最高出力は, 市 販の室温動作可能な校正された検出器で容易に検出する ことができる水準に達している.

一方, 光波からのエネルギー変換効率は約 $10^{-6}$ 程度で

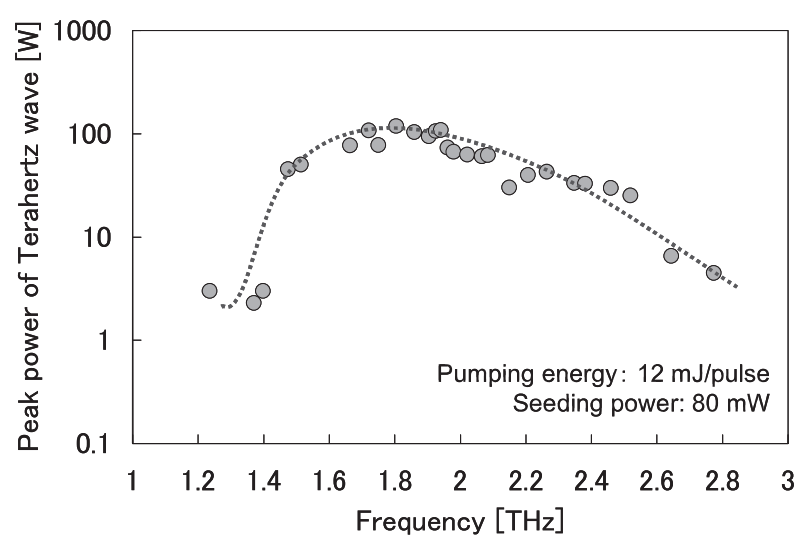

Fig. 5 Tunability of an injection-seeded terahertz-wave parametric generator.

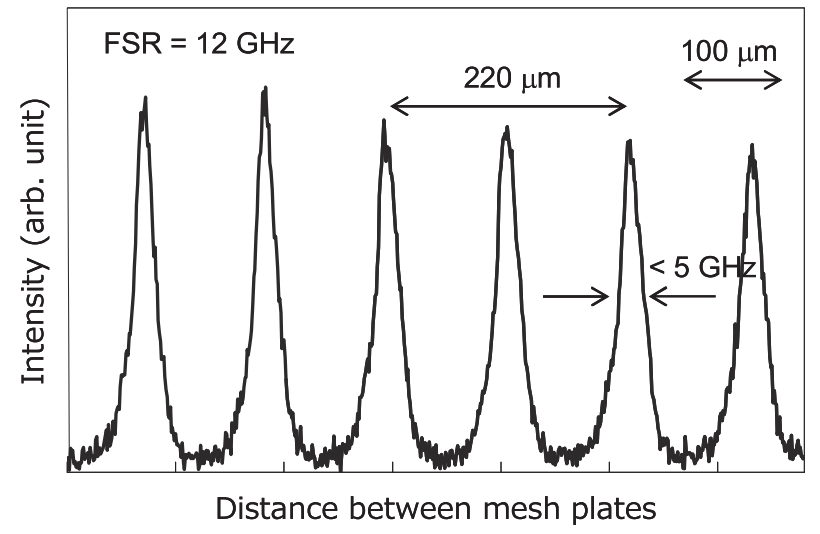

Fig. 6 Wavelength and linewidth of the terahertz-wave measured with a scanning Fabry-Perot etalon consisting of two metal mesh plates. The stability of the spectrum is demonstrated and the displacement between the two periods $(220 \mu \mathrm{m})$ corresponds directly to the wavelength. The FSR of the etalon is $12 \mathrm{GHz}$ and the linewidth of the terahertz wave is measured to be less than $5 \mathrm{GHz}$.

あり(理論的にはマンリー・ロー限界により最大 $10^{-2} ま$ で得られる), 光学系の最適化や結晶冷却による吸収損 失の低減によって更に10～100倍の改善ができると期待 されている27,28).

Fig. 6に, メタルメッシュエタロンによる出力テラヘ ルツ光の出力安定性および波長計測, 発生線幅計測の結 果を示す。メタルメッシュ間の距離を変化させ，2種類 のFSRについて計測を行った。摇らぎの少ない安定した 動作を観測した。メタルメッシュエタロンの透過テラヘ ルツ光強度変化より, 波長約 $220 \mu \mathrm{m}$ (周波数約 $1.4 \mathrm{THz}$ ), 発生線幅 $5 \mathrm{GHz}$ 以下と見積もることができる，光注入を 行った結果，パルス幅によって制限されるフーリエ限界 に迫る狭線幅のテラヘルツ光が発生していることがわか る.

Fig. 7に，ワイアーグリッド偏光子透過率の角度依存 性を示す。図中の $0,180,360$ 度付近のとき, ワイアー 方向が垂直方向になるよう配置した。 テラヘルツ光の透 過率が計算結果 $\left(\sin ^{2}\right.$ (ワイアーグリッドの回転角度 $\left.)\right) に$

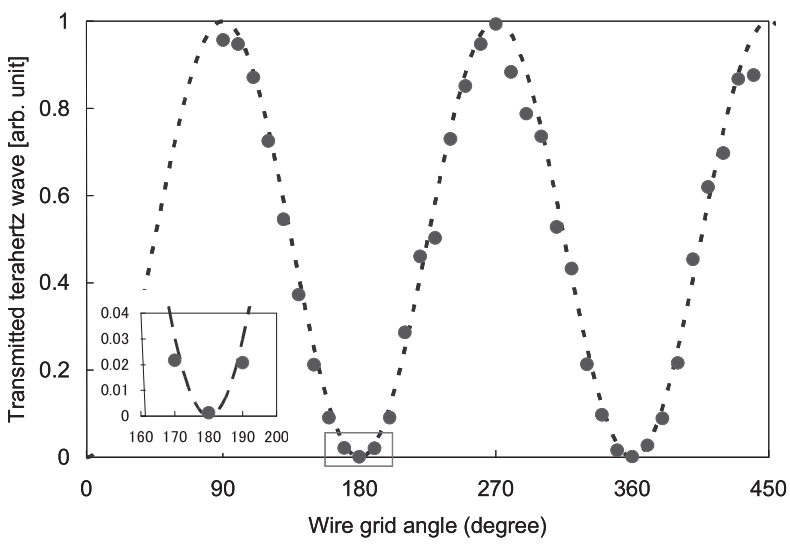

Fig. 7 Polarization measurement using wire grid polarizer. A inset shows magnified figure of rectangle area around 180 degree of wire grid angle. 
よる計算結果とよく一致していることから, 直線偏光で あることが分かる。差し込み図は透過テラヘルツ光強度 が最低となるワイアーグリッドの回転角度が180度付近 を拡大して示してある。最高拈よび最低の透過率より求

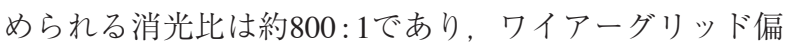
光子の限界に達している.

\section{5. まとめ}

サブナノ秒のパルス幅, 単一縦モード発振のマイクロ チップNd:YAGレーザーを増幅し，励起光源として用い ることによって，テラヘルツ光の大幅な高出力化を達成 した。A3紙程度の小型テラヘルッ光パラメトリック光 源から, 最高出力 $120 \mathrm{~W}$ (尖頭值)，波長可変範囲1.2 $2.8 \mathrm{THz}$ ，発振線幅 $5 \mathrm{GHz}$ 以下，偏光度800:1以上のテラ ヘルツ光を発生させ, 観測した。 このコンパクトな高出 力波長可変テラヘルツ光源は, 常温動作で操作も簡便で あり，検出にも常温動作の焦電素子が利用できることか らテラヘルツ領域における応用研究において有力なツー ルとなることが期待される。

\section{謝 辞}

本研究を進めるにあたりご協力いただいた，分子研の 平等拓範准教授, 理研の緑川克美ディレクター, 伊藤弘昌サブディレクター, 大谷知行チームリーダー 保科 宏道研究員に深く感謝いたします

\section{参考文献}

1) 伊藤 弘昌：応用物理 79 (2010) 524.

2) M. Tonouchi: Nature Photonics 1 (2007) 97

3) D. Dragoman and M. Dragoman: Prog. Quantum Electron. 28 (2004) 1 .
4) 斗内 政吉監修：テラヘルツ波新産業(シーエムシー出版, 2011).

5) T. Kleine-Ostmann and T. Nagatsuma: J. Infrared Millim. Terahertz Waves 32 (2011) 143

6) M. Hangyo, M. Tani, and T. Nagashima: Int. J. Infrared and Millim. Waves 26 (2005) 1661.

7) P. H. Siegel: IEEE Trans. Micro. Theory Tech. 52 (2004) 2438

8) P. R. Smith, D. H. Auston, and M. C. Nuss: IEEE J. Quantum Electron. 24 (1998) 255.

9) P. Y. Han and X.-C. Zhang: Appl. Phys. Lett. 73 (1998) 3049.

10) D. M. Mittleman, R. H. Jacobsen, and M. C. Nuss: IEEE J. Sel. Top. Quantum Electron. 2 (1996) 679.

11) R. A. Cheville, R. W. McGowan, and D. Grischkowsky: Phys. Rev. Lett. 80 (1998) 269.

12) J. Allen: Free Electron Lasers and Other Advanced Sources of Light (National Academy Press, Washington, DC, 1994).

13) S. Komiyama: Phys. Rev. Lett. 48 (1982) 271.

14) E. B. Brown, K. A. McIntosh, K. B. Nichols, and C. L. Dennis: Appl. Phys. Lett. 66 (1995) 285.

15) J. Faist, F. Capasso, D. L. Sivco, C. Sirtori, A. L. Hutchinson, and A. Y. Cho: Science 264 (1994) 553.

16) J. Hebling, K. L. Yeh, M. C. Hoffmann, B. Bartal, and K. A. Nelson: J. Opt. Soc. Am. B 25 (2008) B6.

17）田中耕一郎, 廣理 英基：固体物理 46 （2011） 689.

18) S. S. Sussman: Microwave Lab. Report No. 1851 (Stanford University, 1970).

19) M. A. Piestrup, R. N. Fleming, and R. H. Pantell: Appl. Phys. Lett. 26 (1975) 418.

20) K. Kawase, J. Shikata, and H. Ito: J. Phys. D: Appl. Phys. 35 (2002) R1

21) Y. R. Shen: The Principle of Nonlinear Optics (John Wiley and Sons, New York, 1984).

22) V. G. Dmitriev, G. G. Gurzadyan, and D. N. Nikogosyan eds.: Handbook of Nonlinear Optical Crystals (Springer-Verlag, Berlin, 1997).

23) E. D. Palik ed.: Handbok of Optical Constants of Solids (Academic Press, San Diego, 1985)

24) J. Shikata, K. Kawase, K. Karino, T. Taniuchi, and H. Ito: IEEE Trans. Microwave Theory Tech. 48 (2000) 653

25) N. Pavel, J. Saikawa, S. Kurimura, and T. Taira: Jpn. J. Appl. Phys. 40 (2001) 1253.

26) H. Sakai, H. Kan, and T. Taira: Opt. Express 16 (2008) 19891.

27) S. Hayashi, K. Nawata, H. Sakai, T. Taira, H. Minamide, and K. Kawase: Opt. Express 20 (2012) 2881

28）南出 泰覀：応用物理 81 (2012) 284 . 